\title{
高層構造物の制振装置 \\ Mass Damper for High-Rise Structure
}

久保充司 *

Atsushi KUBO

\section{1。まえがき}

近年, 東京スカイツリーに代表されるように, 建築物, タワーなどが高層化するとともに, 構造の合理化, 経済 性の追求, 風や地震に対寸る安心・安全性が必須のもの となっている。これに伴い，構造物の風摇れ抑制用の制 振装置の設置は必須技術であるが，近年特に大地震（長 周期地震動含む）に対する制振性能ならびに装置安全性 が求められる。

本論では超高層建築物の風摇れ制振装置として設置し た $\mathrm{AMD}, \mathrm{TMD}$ を紹介寸るとともにいわゆるマスダンパ 一に関する今後の課題について述べる。

\section{2. 超高層ビル用 $\mathrm{AMD}$}

\section{1 概要}

本装置は, センサで検知した建物の摇れと振動体の摇 れをもとにPLC とサーボモータで振動体の動きをコント ロールするもので，振動体はビルの周期と同調させ，か つ，階高に収まるように多段に吊られている。この AMD は建物の摇れと同調して自然に摇れだす特性と振り子の 復元力を活用しているため, 周期のない（建物と同調し ない）通常の AMD に較べて駆動力や消費電力を大幅に セーブできるだけでなく, 大型化・長ストローク化が比 較的容易にできる特長を持つ。

装置方式の違いはあるが，本 AMD は国内・海外を含 め，56 建物に採用されている。

\section{2 構造・機能 ${ }^{1)}$}

装置は多段振り子部とその下に納められた駆動部とで 構成されている。構造を図 1 に示寸。多段振り子部はフ レームの中心に振動体が吊ってあり, フレームはロープ によって互いに結ばれ最外部のフレームのみ建物床に固 定される。各ロープには, フレームの柱に沿って上下し, ロープの有効振り子長さを変えて周期を調整できる固有 周期調整装置を設けている。

駆動部は $\mathrm{AC}$ サーボモータ, ボールねじ, $\mathrm{X} ・ \mathrm{Y}$ ビーム, $\mathrm{X} \cdot \mathrm{Y}$ ジョイント及び駆動部と振動体を連結する摺動部よ り構成されており, 2 方向同時制御ができる機構となって いる。摺動結合部は上下方向にスライドし，スライドす るピストンの下端は回転に対して自由なユニバーサルジ ヨイントとなっており，製作誤差，据付誤差などを吸収 できる機構を採用している。

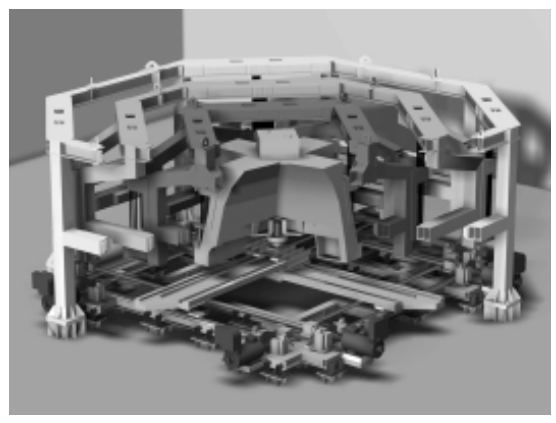

図 1 多段振り子式AMD

* 三菱重工鉄構エンジニアリング(株) 免制振グループ 主事 Acting Manager, Vibration Control Systems Group, Engineering Department, Mitsubishi Heavy Industries Bridge \& Steel Structures Engineering CO., LTD 


\section{3 性能確認試験}

AMD により建物に付加される減衰定数の確認を目的 として，すべての納入建物で竣工前の実建物による加振 実験を行い，性能確認を行っている。図 2 はその一例 ${ }^{2)}$ で AMD を起振機として用いて建物を加振し，建物加振 停止後の自由振動波形から減衰定数を評価している。上 から装置停止時, TMD として作動させた時, AMD 作動 時の試験結果を示す。AMD 作動時には 10.6\%の減衰定数 が確認され，解析值 $9.6 \%$ と整合する結果が得られてい る。
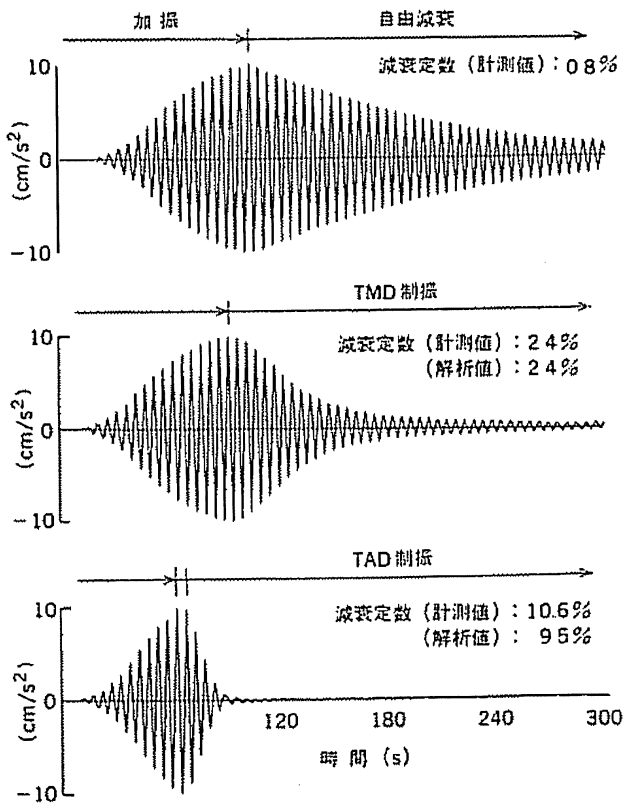

図 2 AMD 性能確認試験

3. 超高層構造物用 TMD

3. 1 煙突 $^{3)}$

\section{(1) 煙突の概要}

超高煙突は周辺環境への配慮が要求される。図 3 に示 寸煙突も, 周辺景観に配慮し自立した 2 筒身の間に外装 板を設置した構造としている。風洞実験の結果, 面内方 向に大きく振動する渦励振が発生することが確認された ため，頂部に TMD を設置した。

煙突は, 発電用の高さ $150 \mathrm{~m}$ の煙突で自立した 2 筒身 (筒 身外形 $\varphi 9.0 \mathrm{~m} ）$ の間に外装板を設置した鋼製 2 筒身集合 形煙突である。

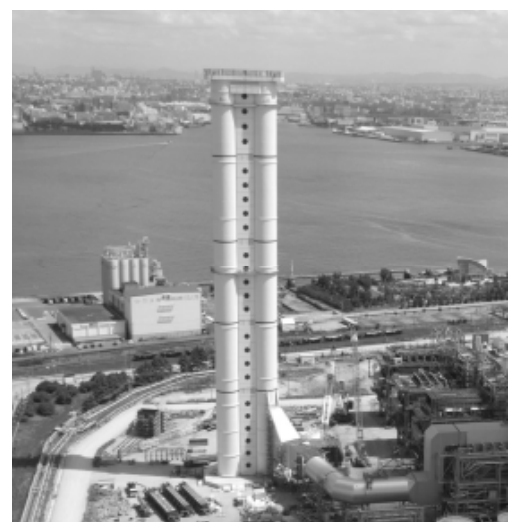

図 3 煙突外観

(2) TMD の概要

各筒身頂部に設置（図 4 参照）した 2 台の装置は，1 台当たり $504 \mathrm{kN}$ の鋼製の錘を積層ゴムで支持し，周期調 整のためにコイルばねを有した装置とした。減衰機構は オイルダンパを採用し，ストロークオーバー時のフェー ルセーフ機構として, 錘の衝撃力を軽減する目的で防弦 材を設置している (図 5 参照)。

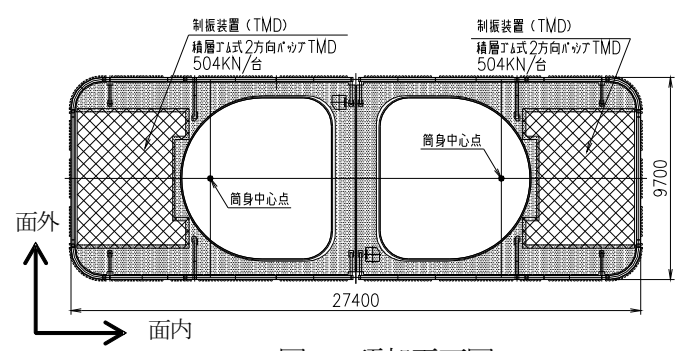

図 4 頂部平面図

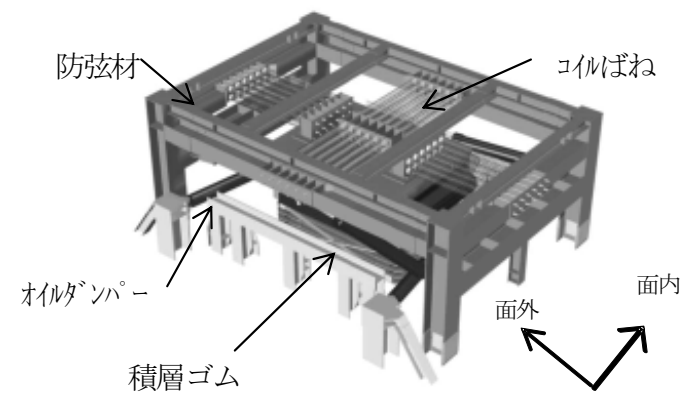

図 5 TMD 概要図

（3）性能確認試験

TMD の性能確認試験では, 人力加振あるいは起振機を 用いた加振試験により制振性能を確認している。本煙突 では，2 台設置している TMDのうち，1台を油圧アクチ ユエータにより起振機として用いた加振試験を行った。 
試験では, 煙突を正弦波加振し, 定常加振状態で起振機 を急停止することにより煙突の自由振動波形を計測した (図 6 参照)。試験の性質上 TMD の 1 台あたりの付加減 衰効果を確認した。TMDによる付加減衰効果の判定基準 を 4\%として, 曲げ 1 次モードに対して面外・面内方向と も約 6\%の付加減衰効果を達成しており, TMD の制振効 果が確認された（表 1 参照）。

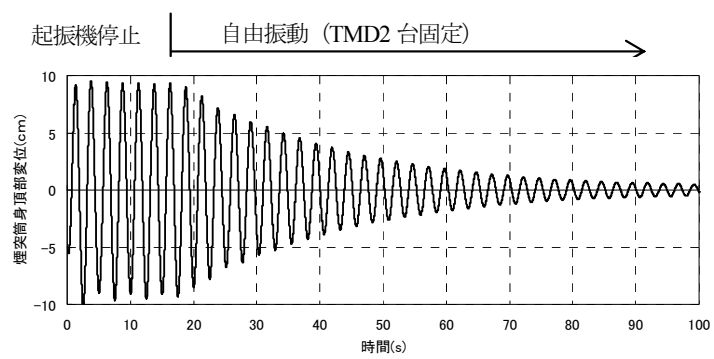

非制振（2 台固定）：加振力約 $10 \mathrm{kN}$

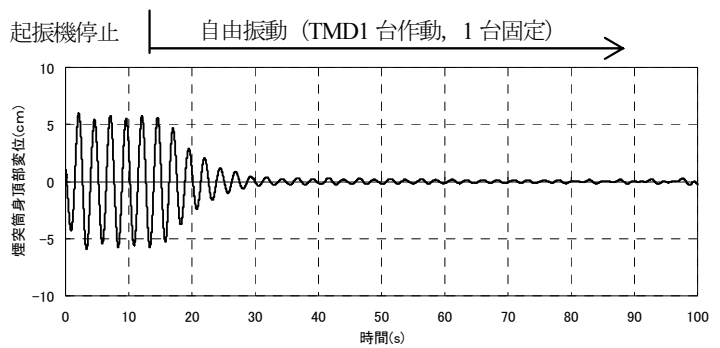

制振（1 台作動， 1 台固定）：加振力約 $30 \mathrm{kN}$

図 6 自由振動試験結果（面外）

表 1 加振試験結果（TMD1 台制振）

\begin{tabular}{|c|c|c|c|}
\hline \multirow[b]{2}{*}{ 方向 } & \multirow{2}{*}{$\begin{array}{l}1 \text { 次固有 } \\
\text { 振動数 }\end{array}$} & \multicolumn{2}{|c|}{ 減衰定数 } \\
\hline & & 非制振 & $\begin{array}{c}\text { 制振 } \\
\text { (1 台作動, } 1 \text { 台固定) }\end{array}$ \\
\hline 面外 & 0.396 & 0.013 & 0.079 \\
\hline 面内 & 0.370 & 0.006 & 0.069 \\
\hline
\end{tabular}

\section{2 東京スカイツリー}

自立式電波塔として世界最高となる東京スカイツリー （634m）のデジタル放送用アンテナなどを支える塔（ゲ イン塔）に対する風摇れ用制振装置として，振動体が $400 \mathrm{kN}, 250 \mathrm{kN}$ の TMD2 台をゲイン塔頂部に設置した (図 7 参照)。

本装置は発生確率の高い日常風によるゲイン塔の変位 速度を一定值以下に抑えることを目的としている。

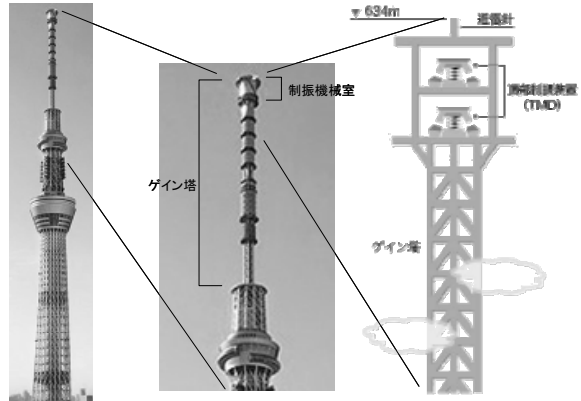

画像提供: 大林組

図 7 ゲイン塔頂部 TMD 設置箇所

図 7 に示寸東京スカイツリーのゲイン塔の頂部 $625 \mathrm{~m}$ $(250 \mathrm{kN}) ， 620 \mathrm{~m}(400 \mathrm{kN})$ に2段に設置されている。構 造的な設置環境制約として設置高さ制限（高さ $5 \mathrm{~m}$ 以下） があるためコンパクトな構造とする必要があったこと, さらに, 従来のパッシブタイプ制振装置以上の長周期に 対応する必要があったことから, 図 8 に示寸倒立振り子 型のパッシブタイプを選定し, 従来構造に改良を加える ことにより，これらの制限，特性を達成可能な構造とし て開発を行った。

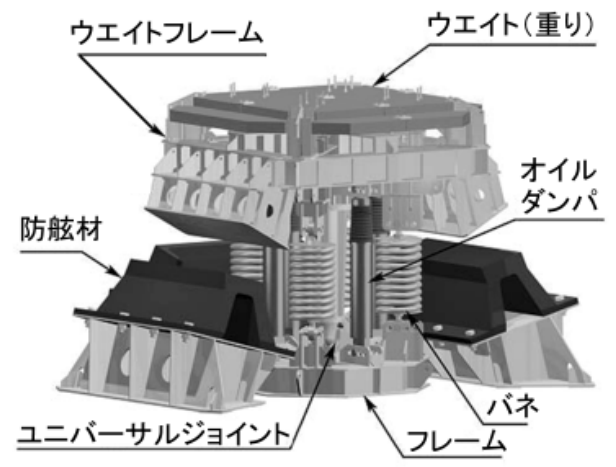

図 8 制振装置の構造概要

構造としては, ウェイトとウェイトフレームからなる 振動体の基部をユニバーサルジョイントが支える構造で あり，押引ばね，オイルダンパなどで構成されている。 また，施工された実構造物の振動特性に合わせて制振装 置の振動特性をチューニングする必要があることから， 現場で振動特性を調整可能な機構を組み込んだ構造とし ている。さらに, 地震のような想定以上の外力が作用し, 装置に過大な振幅が発生した場合でも，装置の損傷につ ながる衝撃的な力を作用させるような急激なブレーキを かけず，ある程度の変位を吸収しながら変位制限をかけ 
る防舷材構造を開発し，ストッパ機構として装置に適用 した。4)

4. マスダンパーの課題

冒頭でも述べたように構造物の風摇れ抑制は当然のこ とであるが，大地震（長周期地震動含む）に対する装置 安全性ならびに制振性能へのニーズは高い。前者は概ね 対応できているが，後者は十分な成果が得られていない のが現状である。

近年，東アジアを中心に特に中国において超々高層ビ ルでの TMD のみならず $\mathrm{AMD}$ の適用要求が高まっている。 $500 \mathrm{~m}$ を超える建物では, 建物規模が大きいだけでなく非 常に長周期となり, 実績装置の 2 3 倍の装置規模が必要 となる。このような建物に対応できる装置の大型化, 長 ストローク化の早期の開発が必要である。

3 点目として, AMD, TMD とも竣工前の建物では性能 評価がなされ，当初の設計どおりの効果が発揮されてい るかの検証は行われている。10 年, 20 年あるいはそれ以 上経過した装置の性能・機能維持を含めたアフターサー ビス対応，手法の確立が必須と考える。

このような課題をひとつひとつ解決す心゙く技術改善・ 開発に取り組んでいきたい。

参考文献

1) 阿比留久徳, 田村一美, 原田秀秋, 松本竹二, 近藤浩, 「高層構造物の制振技術」，三菱重工技報，Vol. 27， No. 5, (1990)

2) 阿比留久徳, 原田秀秋, 尾木靖夫, 山崎信司, 溜正 俊，「高層ビル用制振装置の開発」，三菱重工技報， Vol. 32, No. 3, (1995)

3）鈴木陽, 金山晴幸, 久保充司, 都築充雄, 大久保浩光, 「TMD を利用した超高煙突の加振試験」, 日本建築 学会学術講演梗概集 B-2 構造 2, pp. 205-206, (2008)

4) 森下邦宏, 笹島圭輔, 富谷祐司, 田阪良治, 久保充司, 「東京スカイツリー用制振装置の開発」, 三菱重工技 報, Vol. 49, No. 1, (2012) 